\title{
Antihyperglycemic, Endothelial protection and Toxicity study of Basil Leaves Extract on Diabetic Rats
}

\author{
Sry Suryani Widjaja ${ }^{1 *(\mathbb{D})}$, Rusdiana Rusdiana ${ }^{1}$, Maya Savira ${ }^{2}$ (D), Rina Amelia $^{3} \mathbb{D}$ \\ ${ }^{1}$ Department of Biochemistry, Faculty of Medicine, Universitas Sumatera Utara, Medan, Indonesia; ${ }^{2}$ Department of Physiology, \\ Faculty of Medicine, Universitas Sumatera Utara, Medan, Indonesia; ${ }^{3}$ Department of Community Medicine and Public Health, \\ Faculty of Medicine, Universitas Sumatera Utara, Medan, Indonesia
}

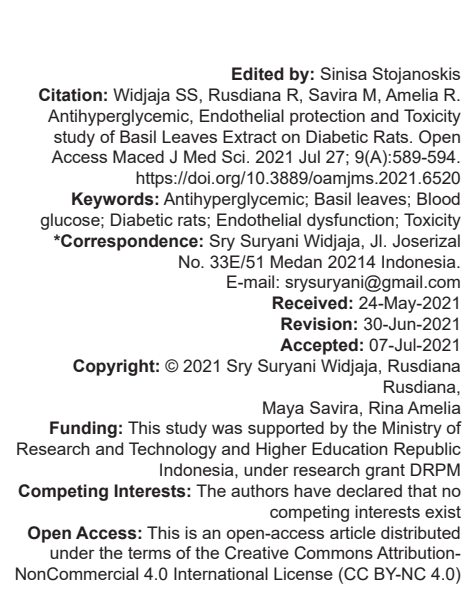

Introduction

Diabetes Mellitus (DM) remains one of the major contributors of preventable chronic disease with an alarming increase in incidence around the world within the past few decades [1], [2]. Type 2 DM (T2DM) compose $90 \%$ of DM cases in adults, imposing a substantial burden, especially in low-and middle-income countries [2], [3], [4]. The underlying key events for the development of T2DM are chronic hyperglycemia and insulin resistance [5]. There is evidence of endothelial dysfunction, macro and microvascular complications that associated with high mortality and morbidity of T2DM patients [6]. Endothelial dysfunction and hyperglycemia heightened vascular damage including the production of advanced glycation end (AGEs) products seen as alteration of Von Willebrand factor ( $v W F$ ) as indication for endothelial function in diabetic microangiopathy [6], [7], [8]. The recommendation for T2DM management focus on achieving long-term good metabolic control through the improvement of lifestyle and pharmacological intervention, which can be seen from both macrovascular and microvascular complication endpoints [9], [10].

Dealing with diabetes and its complications requires very high patient compliance as the gold standard of treatment is the combination of diet, exercise, and medicine [11]. Standard drugs to control blood sugar levels and their complications have been circulating, but morbidity and mortality rates are still high, arguably, due to noncompliance with medication or fear of consuming drugs in the long term [12], [13]. Indonesia, particularly, with approximately 14 million T2DM patients, the fifth largest in the world, has been finding the importance of alternative treatments which are found abundant in herbal alternatives [14], [15].

Basil or Ocimum basilicum is a culinary herb of the Ocimum family or known as mints, abundantly found in Asia. The anti-diabetic properties have only been investigated in a few in vitro studies albeit showing a potential of lowering blood glucose level (BGL) through inhibition of the carbohydrate metabolizing enzyme, namely, amylase and glucosidase [16], [17], [18], [19]. 
Indonesia's archipelago and plethora of diverse medicinal plants have pioneered various studies on traditional medicines, including the usage of readily available basil leaves [20], [21], [22], [23]. Hence, it is imperative to further investigate basil leaves efficacy in the study using rats models.

\section{Methods}

This study was done after getting approved from the Health Research Ethical Committee Medical faculty of Universitas Sumatera Utara/H Adam malik General hospital number: 450/TGL/KEPK FK-USU-RSUPHAM/2018.

\section{Preparation of basil extract}

Basil extract was made using macerated dried Ocimum sanctum. The ground fine powder was extracted using $96 \%$ ethanol solution. The ethanol extract of basil leaves went through standardization using azeotropic distilation, gravimetry, and chromatography to determine water content, water solubility, and ethanol extract content, total ash content, acid insoluble content, as well as chromatogram profile. Afterward, suspension of each basil extract was made by mixing specific concentrations with carboxymethyl cellulose (CMC-Na) $2.0 \%$ solution.

\section{Preparation of experimental animals, induction of diabetes, and introduction of extract}

Male white Wistar rats of 180-200 g weight were prepared for two weeks to adapt to their surroundings, exposed to alternate $12 \mathrm{~h}$ of light and dark. Diabetes was induced by Streptozosin (STZ) injection. The STZ solution was prepared by dissolving STZ in a $50 \mathrm{mmol} / \mathrm{L}$ citrate buffer solution.

Wistar rats were fasted for approximately 18 hours, body weight (BW) weighed, and fasting blood sugar levels measured using the GlucoDr tool to obtain baseline data. STZ solution in citrate buffer $55 \mathrm{mg} / \mathrm{kg}$ BW was given through intraperitoneal injection. Rats blood sugar levels were measured on the $3^{\text {rd }}$ and $7^{\text {th }}$ days. On the $7^{\text {th }}$ day, rats with BGLs higher than $250 \mathrm{mg} / \mathrm{dl}$ were grouped into tested group. Rats with blood sugar levels lower than $250 \mathrm{mg} / \mathrm{dl}$ were induced again. If on the $3^{\text {rd }}$ day the BGL of the test animal is more than $250 \mathrm{mg} / \mathrm{dl}$, then the rats would be grouped into treatment group.
Suspension of the test material (Basil extract) was administered orally and BGLs were measured on the $3^{\text {rd }}, 7^{\text {th }}$, and $10^{\text {th }}$ day after STZ induction. Each treatment group will be given basil extract dosage of $100,300,1000 \mathrm{mg} / \mathrm{kgBW}$, respectively.

\section{Antihyperglycemic effect of the basil extract}

To evaluate the antihyperglycemic effect of basil extract, a total of 25 rats weigh $180-200 \mathrm{~g}$ were divided into five groups, which consist of three treatment groups of dosage $(n=5)$ of 100,300 , and $1000 \mathrm{mg}$, negative control group (normal rats), and positive control (diabetic rats without treatment). BGL was measured at days 0,3 , and 7 after STZ induction. Basil extract treatment started on day 7 . The follow-up measurements of blood glucose was conducted at day $0,3,6,9,12$, and 14 after treatment.

\section{AGE, tumor necrosis factor (TNF)- $\alpha$, vWF level assessment in rats}

The values of the soluble AGE, TNF- $\alpha$, interleukin (IL)-6, IL-2 were determined using a kit obtained from Fine Test and performed using the enzyme-linked immunosorbent assay method.

\section{Toxicity study}

A total of 50 rats induced with $50 \mathrm{mg} / \mathrm{kg} \mathrm{BW}$ STZ solution underwent acute, subacute, and chronic toxicity study. Acute toxicity study utilizes lethal dose of 1500,3000 , and $5000 \mathrm{mg}$, subacute and chronic toxicity study at 100, 300, and $1000 \mathrm{mg}$. Evaluation of toxicity study comprised of BGL, liver function tests (Serum glutamic oxaloacetic transaminase [SGOT], serum glutamic pyruvic transaminase [SGPT], Alkaline Phosphatase, Gamma GT), kidney function tests (Urea and Creatinine), and endothelial activation ( $\mathrm{vWF}$ and prothrombin fragment $\mathrm{F} 1+2$ ) of the STZ-induced rats.

Further, histopathological examination was conducted to evaluate toxicity through assessment of necrosis of liver cells, kidney cells, pancreas, heart, lung, brain parenchymal cells with $\mathrm{H}$ and $\mathrm{E}$ staining.

\section{Statistical analysis}

Statistical analysis was done on PRISM GraphPad version 8 and Statistical Package for Social Sciences. One-way analysis of variance and Post-hoc Tamhane test was done. The aqua dest control group was compared with the diabetic group. Data were expressed as mean \pm Standard deviation. The results were rationally analyzed and $p<0.05$ was considered statistically significant. 


\section{Results}

\section{Baseline data of rats}

To obtain baseline value, twenty-five male Wistar rats were selected, with average weight of 184.7 $\pm 13.6 \mathrm{~g}$ and average BGL $78.8 \pm 9.0 \mathrm{mg} / \mathrm{dL}$.

\section{Effect on BGL}

There was a consistent reduction on the average BGL after being given $100 \mathrm{mg} / \mathrm{kg}$ BW basil extract from $423 \mathrm{mg} / \mathrm{dL}$ on day 0 , to day $3,6,9,12$, and 14 , respectively, at $384 \mathrm{mg} / \mathrm{dl}, 268 \mathrm{mg} \mathrm{dl}, 189 \mathrm{mg} / \mathrm{dl}$, $126 \mathrm{mg} / \mathrm{dl}$, and $102 \mathrm{mg} / \mathrm{dl}$. Similar reduction was found after $300 \mathrm{mg} / \mathrm{kg}$ BW basil extract administration, starting from 487 on day $0,401.6 \mathrm{mg} / \mathrm{dL}$ at day 3 to $283 \mathrm{mg} / \mathrm{dl}$ on day 6,214 on day $0,137 \mathrm{mg} / \mathrm{dL}$ on day 12 , and $93.3 \mathrm{mg} / \mathrm{dL}$ on day 14 [Figure 1].

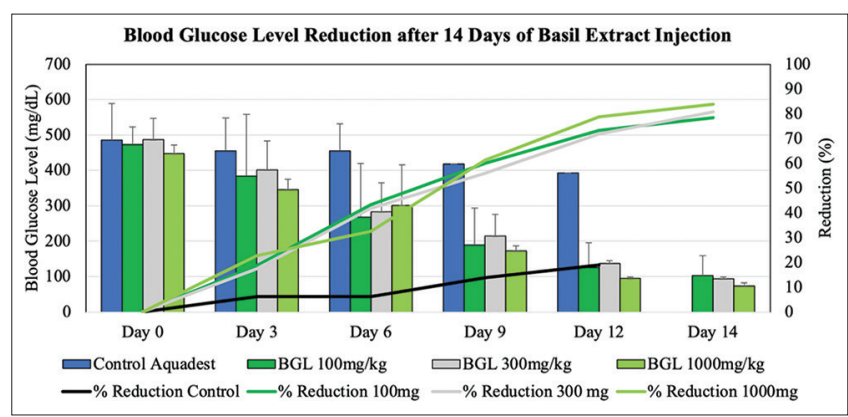

Figure 1: Comparison of antihyperglycemic effect between dose $100 \mathrm{mg} / \mathrm{kgBW}, 300 \mathrm{mg} / \mathrm{kgBW}$, and $1000 \mathrm{mg} / \mathrm{kg} \mathrm{BW}$

Overall, the highest reduction of BGL was achieved with Basil extract $1000 \mathrm{mg} / \mathrm{kg} \mathrm{BW}$ at $83.75 \%$ followed by dosage $300 \mathrm{mg} / \mathrm{kg}$ BW at $80.34 \%$, and finally the least dosage $100 \mathrm{mg} / \mathrm{kg}$ BW at $78.43 \%$. In addition, control group did not complete the 14 days test, $80 \%$ of control sample died before day 14 . Statistically, through the one-way ANOVA Post hoc Tamhane test, the reduction of $B G L$ showed significant difference $(p<0.00)$ compared to control. However, the end result of BGL between dosage groups at day 14 did not yield statistically significant difference.

\section{Results of Hemostatic Parameters Assessment in Rats}

A total of 18 male Wistar rats were tested for changes in inflammatory and endothelial activation markers such as AGE, TNF- $\alpha$, and vWF levels. We found no statistically significant difference of AGE level between normal control and basil leaves extract on all three dosages of $100 \mathrm{mg}(p=0,12), 200 \mathrm{mg}(p=0,33)$, and $400 \mathrm{mg}(\mathrm{p}=0,26)$. On the other hand, basil leaves extract showed significant reduction of endothelial activation shown by WF and TNF- $\alpha$ reduction compared to control.

Table 1: Blood chemistry markers on acute toxicity study obtained after lethal dose of basil extract

\begin{tabular}{lllllll}
\hline Parameter & $\begin{array}{l}\text { SGOT } \\
\text { (IU/L) }\end{array}$ & $\begin{array}{l}\text { SGPT } \\
\text { (IU/L) }\end{array}$ & $\begin{array}{l}\text { Alkaline } \\
\text { Phosphatase (IU/L) })\end{array}$ & $\begin{array}{l}\text { Gamma } \\
\text { GT }(\mathrm{U} / \mathrm{L})\end{array}$ & $\begin{array}{l}\text { Urea } \\
(\mathrm{mg} / \mathrm{dL})\end{array}$ & $\begin{array}{l}\text { Creatinine } \\
(\mathrm{mg} / \mathrm{dL})\end{array}$ \\
\hline Control & 100 & 33 & 371 & 3.6 & 57.3 & 0.46 \\
Basil $1500 \mathrm{mg}$ & 142 & 41 & 510 & 16 & 110 & 0.40 \\
Basil $3000 \mathrm{mg}$ & 93 & 30 & 566 & 11 & 77 & 0.30 \\
Basil $5000 \mathrm{mg}$ & 110 & 37 & 686 & 13 & 97 & 0.43 \\
\hline
\end{tabular}

SGOT: Serum glutamic oxaloacetic transaminase, SGPT: Serum glutamic pyruvic transaminase.

\section{Toxicity study}

\section{Effects on biochemical parameters}

The acute toxicity study conducted did not show any morbidity or mortality, behavioral changes, or other symptoms. The blood chemistry markers on three dosages were within normal limits albeit slight elevation in SGPT, alkaline phosphatase, Gamma GT, and Urea levels, however, there was no statistically significant difference compared to control [Table 1]. The biochemical reference range for SGOT is $44-147 \mathrm{IU} / \mathrm{L}$, SGPT 10-40 IU/L, ALP 50-150 IU/L, Gamma GT 1-5.3 $\mathrm{U} / \mathrm{L}$, urea $15-45 \mathrm{mg} / \mathrm{dL}$, and creatinine $0.2-0.8 \mathrm{mg} / \mathrm{dL}$ [24], [25], [26], [27].

Table 2: Blood chemistry markers on subacute toxicity study

\begin{tabular}{lllllll}
\hline Parameter & $\begin{array}{l}\text { SGOT } \\
\text { (IU/L) }\end{array}$ & $\begin{array}{l}\text { SGPT } \\
\text { (IU/L) }\end{array}$ & $\begin{array}{l}\text { Alkaline } \\
\text { Phosphatase (IU/L) })\end{array}$ & $\begin{array}{l}\text { Gamma } \\
\text { GT }(\mathrm{U} / \mathrm{L})\end{array}$ & $\begin{array}{l}\text { Urea } \\
(\mathrm{mg} / \mathrm{dL})\end{array}$ & $\begin{array}{l}\text { Creatinine } \\
(\mathrm{mg} / \mathrm{dL})\end{array}$ \\
\hline Control & 24 & 140 & 275 & 25 & 41 & 0.37 \\
Basil $100 \mathrm{mg}$ & 69 & 165 & 255 & 30 & 53 & 0.43 \\
Basil $300 \mathrm{mg}$ & 66 & 183 & 300 & 28 & 86 & 0.38 \\
Basil $1000 \mathrm{mg}$ & 35 & 102 & 280 & 13 & 40 & 0.51 \\
\hline SGOT Ser
\end{tabular}

As for the subacute toxicity study, throughout the period, there were no observed changes, symptoms, or behavioral and neurological alterations. There is no morbidity or mortality in all rate samples. The differences within and between groups are not significant [Table 2].

Table 3: Blood chemistry markers on chronic toxicity study

\begin{tabular}{lllllll}
\hline Parameter & $\begin{array}{l}\text { SGOT } \\
(\mathrm{IU} / \mathrm{L})\end{array}$ & $\begin{array}{l}\text { SGPT } \\
(\mathrm{IU} / \mathrm{L})\end{array}$ & $\begin{array}{l}\text { Alkaline } \\
\text { Phosphatase (IU/L) }\end{array}$ & $\begin{array}{l}\text { Gamma } \\
\mathrm{GT}(\mathrm{U} / \mathrm{L})\end{array}$ & $\begin{array}{l}\text { Urea } \\
(\mathrm{mg} / \mathrm{dL})\end{array}$ & $\begin{array}{l}\text { Creatinine } \\
(\mathrm{mg} / \mathrm{dL})\end{array}$ \\
\hline Control & 148.32 & 35 & 368 & 21.55 & 25.06 & 0.32 \\
Basil $100 \mathrm{mg}$ & 88.99 & 35.66 & 377 & 11.8 & 30 & 0.43 \\
Basil $300 \mathrm{mg}$ & 138.99 & 47.32 & 394 & 16.22 & $28 ., 5$ & 0.35 \\
Basil $1000 \mathrm{mg}$ & 70.33 & 32.66 & 302 & 13.8 & 49.2 & 0.4 \\
\hline
\end{tabular}

Chronic toxicity study of basil leaves extracts effect on the treatment batch yields no changes in morbidity and mortality. There were inconsistent variations and increases of liver and kidney function tests results between dosages, however, the treatment groups showed no statistical differences compared to control group [Table 3].

Despite showing elevated numbers of alkaline phosphatase, and gamma GT, evaluation of blood chemistry markers of liver damage (SGOT, SGPT, Alkaline phosphatase, and gamma GT), markers of kidney damage (urea and creatinine) did not show significant differences between treatment group and control as well as within group. 


\section{Histopathological findings}

Histopathological assessment on sections of the liver, kidney, heart, pancreas, lung, and lymph using light microscopy to assess the effect of basil leaves extract in STZ-induced diabetic tissues. Pathologically, all organ sections in all dosage groups did not show anatomical abnormalities administration compared to control group [Figure 2].

Liver cells showed normal and uniform arrangements of hepatocytes. Neither hepatocytes destruction nor congested hepatic inflammation was seen. In regards to lymph biopsy, there is no congestion or necrosis indicative of lymph damage. In all treatment and control groups, the renal tissue showed normal glomeruli, the epithelial lining of Bowman's capsule and mesangial cells, and no necrotic tissue found. The tubules were preserved well with normal columnar epithelial cells. Normal lung biopsy was obtained, the alveolar sac was not clearly seen. There is no foamy macrophage seen despite increase of infiltrate in the rat lung tissue. The pancreas was found normal, there was no evident of necrosis, degranulation, or shrinkage particularly in Langerhans Islet.

\section{Discussion}

Basil leaves is one of the numerous medicinal herbs recommended for Diabetes treatment. Previously, basil extract was found to decrease the classic Diabetes symptoms, namely, polydipsia, polyphagia, and polyuria in 30 T2DM patients with consumption of $2 \mathrm{~g}$ basil leaf powder for 3 months daily [28]. In the present study, the effects, dosage, and toxicity of the basil leaves extract were evaluated in concordance to its anti-inflammatory properties.

Basil leaves, herbs from the Ocimum family have been proposed to possess antihyperglycemic properties in multiple studies [16], [17], [20], [29], [30], [31]. This study found significant blood glucose -lowering effect and endothelial protection of basil leaves. The findings are consistent with our previous study which also elucidates that basil leaves extract effectivity to reduce blood glucose was on par with Metformin $50 \mathrm{mg} / \mathrm{kg} \mathrm{BW}$ control group [18].

Insulin-secretory effect of the Ocimum family was elucidated by Hannan et al., as the extract enhances effects of insulin secretion from the pancreas, isolated islets, and modulation of intracellular calcium [30]. Basil leaves also shown to possess insulinotropic effect through the enhancement of physiological pathways on pancreatic beta-cells [20]. Thus, increasing plasma insulin and decreasing BGL in rats with type 2 diabetes [30].

In regard to biochemical markers, there is still lack of in-depth studies on the toxicity effect and biochemical profile of basil leaves. One attempt, by Huq et al., in a basil-based tea, found that in addition to antidiabetic effect, there are no harmful effects on the liver by evaluation of SGPT [32], [33]. The antiinflammatory effect of Ocimum sanctum was lacking as well. However, Ocimum tenuiflorum has been researched to possess pharmacological activities involving reduction of lipid peroxidation, increasing uptake of radical scavenging activity, and stimulation of antioxidant enzymes [33], [34].

Through histopathological biopsy, this study found normal results in the liver, kidney, lymph, lung,

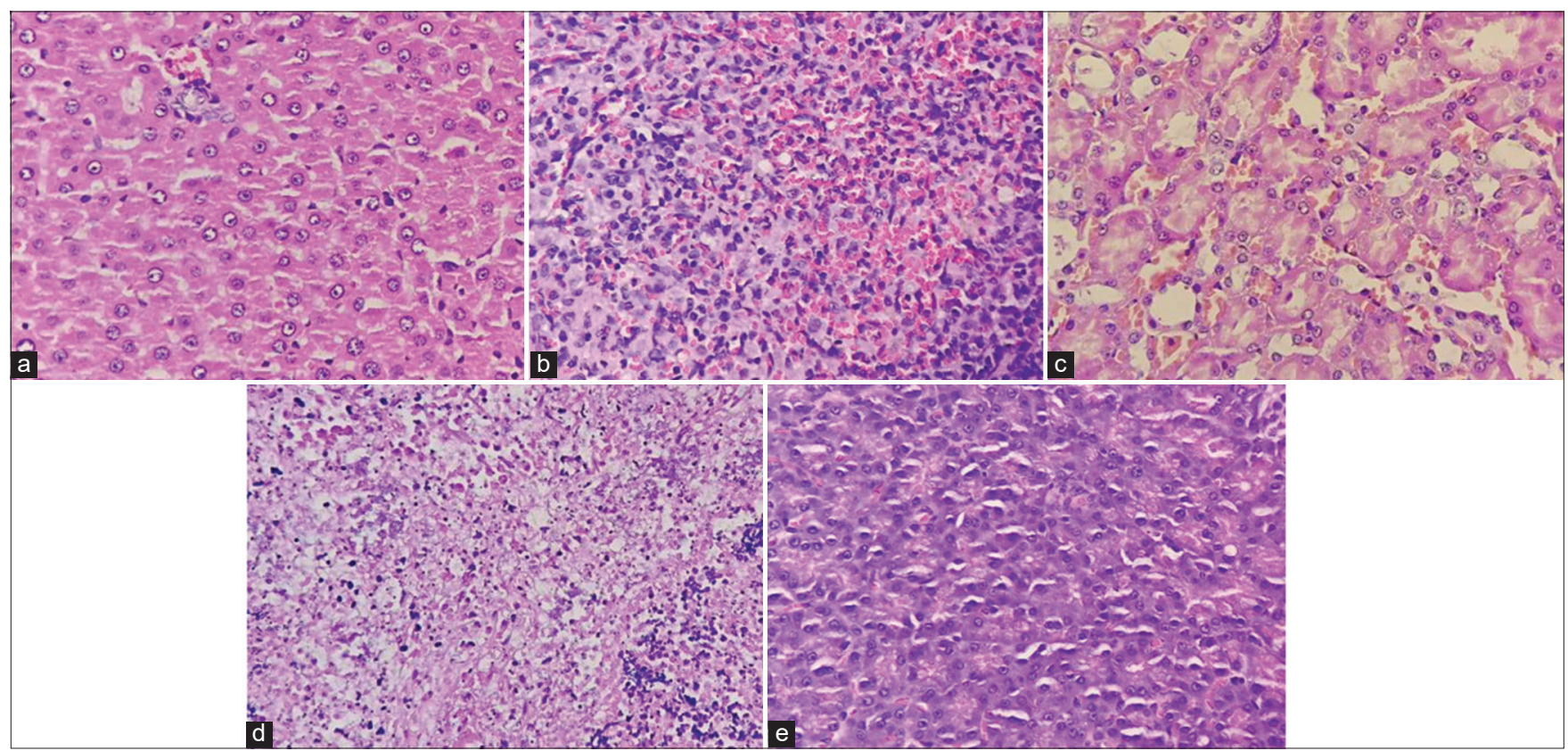

Figure 2: Comparison of microscopic representation of histological sections in toxicity study. (a) Liver (b) Lymph (c) Kidney (d) Lung (e) Pancreas 
and pancreas which are in concordance with the biochemical markers from blood tests. SGOT and SGPT were slightly increased but none of which showed significance difference compared to their control sample counterparts. In addition, all of the Wistar rats results of SGPT were increased. It is known that SGOT is the least specific of the two because SGOT was not only produced by the liver but also by the heart. On the other hand, SGPT directly reflects liver damage as it is directly produced by liver cells. Therefore, SGPT is the more reliable marker along with liver enzymes such as alkaline phosphatase [35], [36]. The increase in SGPT, ALP, and Gamma GT might indicate liver damage, however, it is debunked as even the normal Wistar rats possess similar levels of SGPT, ALP, and Gamma GT.

\section{Conclusions}

This study confirmed the antihyperglycemic and antiinflammatory effects of basil leaves (Ocimum sanctum), as well as safety in acute, subacute, and chronic setting. This study will be the pioneer to further unravel the potential of basil leaves extract for Diabetes treatment. In the future, more work needs to be directed in achieving characterization of active components and human trials to be further formulated into novel antidiabetic agents.

\section{References}

1. Zheng Y, Ley SH, Hu FB. Global aetiology and epidemiology of type 2 diabetes mellitus and its complications. Nat Rev Endocrinol. 2018;14(2):88-98. https://doi.org/10.1038/ nrendo.2017.151

PMid:29219149

2. Magliano DJ, Islam RM, Barr EL, Gregg EW, Pavkov ME, Harding JL, et al. Trends in incidence of total or Type 2 diabetes: Systematic review. BMJ. 2019;366:I5003. https://doi. org $/ 10.1136 / \mathrm{bmj} .15003$

PMid:31511236

3. Afroz A, Alramadan MJ, Hossain MN, Romero L, Alam K, Magliano DJ, et al. Cost-of-illness of Type 2 diabetes mellitus in low and lower-middle income countries: A systematic review. BMC Health Serv Res. 2018;18(1):972. https://doi.org/10.1186/ s12913-018-3772-8

PMid:30558591

4. Manne-Goehler J, Geldsetzer P, Agoudavi K, Andall-Brereton G, Aryal KK, Bicaba BW, et al. Health system performance for people with diabetes in 28 low-and middle-income countries: A cross-sectional study of nationally representative surveys. PLoS Med. 2019;16(3):e1002751. https://doi.org/10.1371/ journal.pmed.1002751

PMid:30822339

5. Schwartz SS, Epstein S, Corkey BE, Grant SF, Gavin JR, Aguilar RB. The time is right for a new classification system for diabetes: Rationale and implications of the $\beta$-cell-centric classification schema. Diabetes Care. 2016;39(2):179-86. https://doi.org/10.2337/dci16-0011

PMid:26798148

6. Chawla A, Chawla R, Jaggi S. Microvasular and macrovascular complications in diabetes mellitus: Distinct or continuum? Indian J Endocrinol Metab. 2016;20(4):546-51. https://doi. org/10.4103/2230-8210.183480

PMid:27366724

7. Mahdi A, Jiao T, Yang J, Kövamees O, Alvarsson M, von Heijne $M$, et al. The effect of glycemic control on endothelial and cardiac dysfunction induced by red blood cells in Type 2 diabetes. Front Pharmacol. 2019;10:861. https://doi. org/10.3389/fphar.2019.00861

PMid:31427970

8. Kaur R, Kaur M, Singh J. Endothelial dysfunction and platelet hyperactivity in type 2 diabetes mellitus: Molecular insights and therapeutic strategies. Cardiovasc Diabetol. 2018;17(1):121. https://doi.org/10.1186/s12933-018-0763-3

PMid:30170601

9. Hasan F, Hasan B. Antidiabetic medications and mortality reduction: A shift from surrogate to clinical endpoints. Ther Adv Endocrinol Metab. 2017;8(12):173-4. https://doi. org/10.1177/2042018817737955

PMid:29238516

10. Marín-Peñalver JJ, Martín-Timón I, Sevillano-Collantes C, De Cañizo-Gómez FJ. Update on the treatment of Type 2 diabetes mellitus. World J Diabetes. 2016;7(17):354-95. https://doi. org/10.4239/wjd.v7.i17.354

PMid:27660695

11. American Diabetes Association. 4. Lifestyle management: Standards of medical care in diabetes-2018. Diabetes Care. 2018;41 Suppl 1:S38-50. https://doi.org/10.2337/dc18-s004 PMid:29222375

12. Polonsky WH, Henry RR. Poor medication adherence in Type 2 diabetes: Recognizing the scope of the problem and its key contributors. Patient Prefer Adherence. 2016;10:1299-307. https://doi.org/10.2147/ppa.s106821 PMid:27524885

13. Cutler RL, Fernandez-Llimos F, Frommer $M$, Benrimoj $C$ Garcia-Cardenas V. Economic impact of medication non-adherence by disease groups: A systematic review. BMJ Open. 2018;8(1):e016982. https://doi.org/10.1136/ bmjopen-2017-016982 PMid:29358417

14. Soewondo P, Ferrario A, Tahapary D. Challenges in diabetes management in Indonesia: A literature review. Global Health. 2013;9(1):63. https://doi.org/10.1186/1744-8603-9-63 PMid:24299164

15. Rudianto A, Soewondo P, Waspadji S, Yunir E, Purnamasari D. The Indonesian society of endocrinology's summary article of diabetes mellitus national clinical practice guidelines. JAFES. 2011;26(1):17-9. https://doi.org/10.15605/jafes.026.01.03

16. El-Beshbishy $\mathrm{H}$, Bahashwan S. Hypoglycemic effect of basil (Ocimum basilicum) aqueous extract is mediated through inhibition of $\alpha$-glucosidase and $\alpha$-amylase activities: An in vitro study. Toxicol Ind Health. 2012;28(1):42-50. https://doi. org/10.1177/0748233711403193

PMid:21636683

17. Ezeani C, Ezenyi I, Okoye T, Okoli C. Ocimum basilicum extract exhibits antidiabetic effects via inhibition of hepatic glucose mobilization and carbohydrate metabolizing enzymes. J Intercult Ethnopharmacol. 2017;6(1):22-8. https://doi.org/10.5455/ jice.20161229054825

PMid:28163956 
18. Widjaja SS, Rusdiana R, Savira M. Glucose lowering effect of basil leaves in diabetic rats. Open Access Maced J Med Sci. 2019;7(9):1415-7. https://doi.org/10.3889/oamjms.2019.293 PMid:31198445

19. Antora RA, Salleh RM. Antihyperglycemic effect of Ocimum plants: A short review. Asian Pac J Trop Biomed. 2017;7(8):7559. https://doi.org/10.1016/j.apjtb.2017.07.010

20. Sari FA, Sandhika W, Yuliawati TH. Tulsi (Ocimum sanctum) leaf ethanol extract reduces inflammatory cell infiltration in aspirin-induced gastritis rats. JKB. 2020;31(1):49. https://doi. org/10.21776/ub.jkb.2020.031.01.10

21. Arozal W, Louisa M, Soetikno V. Selected Indonesian medicinal plants for the management of metabolic syndrome: Molecular basis and recent studies. Front Cardiovasc Med. 2020;7:82. https://doi.org/10.3389/fcvm.2020.00082 PMid:32435657

22. Pengpid S, Peltzer K. Use of traditional medicines and traditional practitioners by children in Indonesia: Findings from a national population survey in 2014-2015. J Multidiscip Healthc. 2019;12:291-8. https://doi.org/10.2147/jmdh.s203343 PMid:31114218

23. Vázquez-Fresno R, Rosana AR, Sajed T, Onookome-Okome T, Wishart NA, Wishart DS. Herbs and spices-biomarkers of intake based on human intervention studies-a systematic review. Genes Nutr. 2019;14(1):18. https://doi.org/10.1186/ s12263-019-0636-8

PMid:31143299

24. Loha M, Mulu A, Abay SM, Ergete W, Geleta B. Acute and subacute toxicity of methanol extract of Syzygium guineense leaves on the histology of the liver and kidney and biochemical compositions of blood in rats. Evid Based Complement Alternat Med. 2019;2019:5702159. https://doi. org/10.1155/2019/5702159

PMid:30956682

25. Owu DU, Osim EE, Ebong PE. Serum liver enzymes profile of Wistar rats following chronic consumption of fresh or oxidized palm oil diets. Acta Trop. 1998;69(1):65-73. https://doi. org/10.1016/s0001-706x(97)00115-0

PMid:9588242

26. Thammitiyagodage MG, de Silva NR, Rathnayake C, Karunakaran R, Wgss K, Gunatillka MM, et al. Biochemical and histopathological changes in Wistar rats after consumption of boiled and un-boiled water from high and low disease prevalent areas for chronic kidney disease of unknown etiology (CKDu) in North Central Province (NCP) and its comparison with low disease prevalent Colombo, Sri Lanka. BMC Nephrol. 2020;21(1):38. https://doi.org/10.1186/s12882-020-1693-3

\section{PMid:32005171}

27. Awotunde OS, Adewoye SO, Dhanabal PS, Hawumba J. Subacute toxicity study of aqueous root extract of Terminalia schimperiana in male Wistar rats. Toxicol Rep. 2019;6:825-32. https://doi.org/10.1016/j.toxrep.2019.07.006 PMid:31463203

28. Kochhar A, Sharma N, Sachdeva R. Effect of supplementation of Tulsi (Ocimum sanctum) and Neem (Azadirachta indica) leaf powder on diabetic symptoms, anthropometric parameters and blood pressure of non-insulin dependent male diabetics. Stud Ethno Med. 2009;3(1):5-9. https://doi.org/10.1080/09735070.20 09.11886330

29. Abilash S, Vijay Y, Deepthi T, Sri C, Vibha R, Swetha R, et al. Anti diabetic effect of ethanolic extract of leaves of Ocimum sanctum in alloxan induced diabetes in rats. Int $\mathrm{J}$ Basic Clin Pharmacol. 2013;2(5):613. https://doi.org/10.5455/2319-2003. ijbcp20131018

30. Hannan JM, Marenah L, Ali L, Rokeya B, Flatt PR, AbdelWahab YH. Ocimum sanctum leaf extracts stimulate insulin secretion from perfused pancreas, isolated islets and clonal pancreatic $\beta$-cells. J Endocrinol. 2006;189(1):127-36. https:// doi.org/10.1677/joe.1.06615

PMid: 16614387

31. Widjaja SS, Rusdiana R. Extract ethanol of poguntano in alloxan induced diabetic rats. Bangladesh J Med Sci. 2018;17(2):251-4. https://doi.org/10.3329/bjms.v17i2.35879

32. Huq A, Haque K, Khan AK. Clinical efficacy and safety of holy basil-based anti-diabetic tea. J Sci Technol. 2018;8(1-2):1-9.

33. Governa P, Baini G, Borgonetti V, Cettolin G, Giachetti D, Magnano A, et al. Phytotherapy in the management of diabetes: A review. Molecules. 2018 4;23(1):105. https://doi.org/10.3390/ molecules23010105 PMid:29300317

34. Pattanayak P, Behera P, Das D, Panda S. Ocimum sanctum Linn. A reservoir plant for therapeutic applications: An overview. Pharmacogn Rev. 2010;4(7):95-105. https://doi. org/10.4103/0973-7847.65323 PMid:22228948

35. Lala V, Goyal A, Bansal P, Minter DA. Liver function test. In: Stat Pearls. Treasure Island, FL: Stat Pearls Publishing; 2020.

36. Ramachandran S, Rajasekaran A, Manisenthilkumar K. Investigation of hypoglycemic, hypolipidemic and antioxidant activities of aqueous extract of Terminalia paniculata bark in diabetic rats. Asian Pac J Trop Biomed. 2012;2(4):262-8. https:// doi.org/10.1016/s2221-1691(12)60020-3

PMid:23569911 